\title{
Research on the Education Mode of Ideological and Political Education of Public Security College Students
}

\author{
Lili Yang \\ Teaching Department of Ideological and Political Theory of Hubei University of Police; Wuhan \\ 430035, China
}

Keywords: Public security college students; Ideological and political education; The main body education.

\begin{abstract}
At present, the public security ideological and political education of college students is facing the new situation. Ideological and political education should pay more attention to students' all-round development, the main purpose of education is to improve ability and build a sound personality for students, so it is necessary to choose the education mode with the main body as the content. This education mode pays close attention to students' needs and care about the improvement of students' quality, it has many advantages.
\end{abstract}

\section{The significance of Implementing Main Body Education Mode to Public Security University Students' Ideological and Political Education.}

At present, the society has developed a higher standard for human resources, so the ideological and political education of colleges and universities should be meet the developing needs of the current society. The public security university is different from the ordinary universities and has certain particularity, so it is necessary to pay more attention to promoting the standard of ideological and political education. Ideological and political education should be benefic to the all-round development of students and highlight the main body of student's ability. through the ideological and political education, we can shape students' personality, this also is the starting point of public security ideological and political education. Due to the rapid development of society, the ideological and political education cannot be in a static state and should be changed according to the characteristics of social development and change.

If we want to make the ideological and political education of public security college students work better, we must let the teachers play a leading role. Because the starting point of ideological and political education is to improve student's quality, so the ideological and political education should be benefic to the all-round development of students, it should cultivate students with sound subjective personality, cultivate their all-round ability. We must consciously promote student's moral standards. The public security college students should have ideal that " The Party was founded for public good and it exercises state power/governance for the people. ", to maintain their loyalty to the law, the party, the motherland and the people. Therefore, the public security academy should pay attention to the goal of education and analyze the characteristics of students when carrying out the ideological and political education. The starting point of education is to improve the quality of students. In the ideological and political education, we must consider the characteristics of students, understand students' physiological and psychological characteristics, teaching them according to their aptitude, strengthen the students' initiative, arouse the students' self-consciousness. So that we can create a unique new mode of ideological and political education that suits our country's situation. The students of public security colleges are the reserve force of the people's police, and it is of great significance to improve the comprehensive quality of students. 


\section{How to Implement the Main-Body Education Mode to Public Security University Students in Their Ideological and Political Education.}

Students' ideological and political education is an important part of the teaching management of public security colleges and universities. Strengthening the ideological and political education can also achieve the "political construction police". The purpose of the school is to train high-quality talents for the public security front. These people need to be both virtuous and dedicated. Therefore, ideological and political education should pay attention to students' characteristics, ability and personality, and establish a new mode of ideological and political education that based on students.

\subsection{The Teaching Method Should be Beneficial to the Development of the Student.}

The content of education should be related to the industry and the theme of the development of The Times. Ideological and political education should have a clear purpose, which is conducive to enhancing education's function and ensuring the education effect of the main body. Ideological and political education should consider the characteristics of the subject and choose a scientific and reasonable way to get a better effect. Public security ideological and political education of college students has certain particularity, it reflected in that the ideological and political education is an important part of the public security education especially in the police team construction, so we must ensure the effect of the ideological and political education. From the fundamental role of the education of ideology and politics, education is also the need of social sustainable development, and the police force is the guarantee of the stable development of society. The orientation of ideological and political education of students in public security practice is to cultivate human resources to meet the need of social development, the public security work requires human resources as a guarantee, so we must improve public security college students training effect during their ideological and political education to make them become useful talents in social development. Therefore, the ideological and political education should pay special attention to the particularity of public security that students will be engaged in the special profession of public safety when they go to society. So, the public security ideological and political education of college students has a dual role, both to ensure that the student individual in the future may well play a role in society, to realize the personalized development of police college students, students' education should pay attention to comprehensive quality and stimulate the creativity of young students. Students are mainly engaged in the work of public security group in the future, student's quality is the foundation of sustainable development to promote the public security work, so the ideological and political education should pay attention to the public security college students to students as a fundamental, attach importance to students' personalized development, will promote the public security college students' comprehensive quality as the focus of ideological and political education. This also reflects the core effect of education.

Due to the development of society and education reform, the public security ideological and political education of college students changed greatly in recent years, Education method pays more attention to the students' subjective initiative and pays more attention to the common and individual characteristics of students in education. Although the management of the public security colleges and universities has the characteristics of mandatory and personalities, but we also noticed that the student individual differences, and change the way of ideological and political education is good to improve the effect of education. Therefore, the establishment of education mode based on students is conducive to improving the effect of education. In the ideological and political education of public security college students, we should consider the unity of social development and human development and enhance the education effect of students' subjects. In specific education practice, the ideological and political education to keep up with the development of The Times, we should guide the public security college students to set up the correct values, guides the student to defined the direction of personal development, improve the students' initiative and creativity. With the development of society, the standards of public security talents are also improving, and students' ideological and political quality should be adjusted to the development and change of society. Therefore, public security colleges should actively adjust the mode of ideological and political education and realize the innovation of education mode according to the needs of social development. 


\subsection{The Content of Teaching Should Meet the Need of Public Security College Students.}

Because the ideological and political education take the students as the main body, so on the design of the education content, we should adopt the way of people-oriented, combined with the characteristics of police college students, educate and guide people, promote the public security college students' comprehensive quality of ascension. The construction of ideological and political education system should fully consider the police college students' main body characteristic and the individual demand, regulating the behavior of the main body of students, should fully respect the principal position of students in education, stimulate students' initiative, to guarantee the effect of the ideological and political education. According to the needs of social transformation and development, the ideological and political education work of public security college students should strengthen the following contents:

First, we should pay attention to character education and elevate the personality level of the subject. The essence of education is character education. In some ways, it is more important to shape the character of a student than to impart knowledge. Especially for public security colleges, helping students to set up correct values is the key point of ideological and political education. The starting point of ideological and political education in public security research institute is to cultivate students with the consciousness of independence, equality, optimistic and enterprising spirit and good psychological quality. These are the essential diathesis for students to work in the future. Due to the development of The Times, quality education of police colleges should change the old way, should not be too much attention to idealism, we should combine the ideological and political education and real life closely, trains the student to have the independence, self-esteem, self-improvement good moral character.

The second is to strengthen the ideological recognition of education. Education's role is to enhance identity. The ideological and political education of public security colleges should give students political recognition. The political identity is reflected in two aspects. The students' political attitude should have psychological compliance and initiative, and the behavior of students should be realistic. Political identity can be reflected in the orientation of political value. Due to the difference of the identity subject and the existence of subjective feelings, it is necessary to have the intervention of the ideological and political education. When we implement education for public security college students, we should combine the political characteristics of reality to help students form the correct value orientation. Students political education can be finally reflected in "loyalty to the party, the people and the law".

The third is to highlight the subject education consciousness. Public security college students are the main part of the ideological and political education, so the ideological and political education should base on the student's main body consciousness, students should learn to be independent, self-reliant and positive, and have active teamwork spirit. They should have the initiative to fulfill their social responsibilities. The main ability of students is also embodied in the ability to acquire knowledge and master skills, and to have innovative consciousness and innovative thinking.

In addition, the public security ideological and political education of college students should also guide the student to study the police professional quality, students should understand the basic connotation of police professionalism and requirements in the new period, Students should firmly establish the sense of responsibility of the police and realize the role of "the people's police for the people" in the future career.

\subsection{Consider Students' Characteristics when Choosing Education Method.}

The ideological and political education should focus on the needs of the subject and reflect the status and role of the subject.

Therefore, in the ideological and political education of public security college students, we should consider the students' characteristics. This should be embodied in the specific teaching methods and means that adhere to the people-centered principle. We should pay attention to motivate student's main body function, initiative and creativity. In combination with the current situation of education in domestic public security institutions, the following methods can be adopted: 
One is to implement interactive education. In the original ideological and political education, the main content of teaching is to explain theoretical knowledge, and the method of teaching is imparting. In this kind of teaching mode, teachers are the main part of the teaching, the teacher plays a leading role. The main content of the teaching is the teacher's explanation to the teaching material that specified by the syllabus of interpretation. Instilling knowledge teaching method has many disadvantages. Students in this kind of classes will be used to learn passively and cannot think divergent in the learning process, they would act as the textbook knowledge receiver. the essence of ideological and political education is moral education which students should learn initiatively, not be forced to accept the education. Therefore, it is necessary to highlight the main role of college students in the ideological and political education and realize the transformation from one-way to two-way interaction the teaching mode should be based on the cultivation of talents to meet the needs of the society. We should change teachers' teaching methods from the original theory teaching into personal quality improving. Teaching design should be based on how to improve the students' comprehensive quality.

The second is to implement the actual education. To improve the effect of education, we should break the traditional teaching method. The past teaching method "Teachers speak, the students listen" has seriously affected the enthusiasm of students', the students thinking ability has been limited to the mode that teacher designed. Some teachers are not good at guiding students to take the initiative in class, and the teaching method is not good, which affects the enthusiasm of students' active thinking. In this situation, teachers should change their teaching methods and change their teaching methods. They should be braver to break the original teaching method and to innovate. Therefore, the content of our teaching should be closely related to social events, and the analysis of events will enable students to get a deeper understanding of the content of the textbook.

In the process that students analyze the social phenomenon by applying the knowledge learned in the ideological and political science, they can realize the important role of education. In addition, teachers should realize that effective teaching is based on improving students' learning effect, while the key to improving students' learning effect is to improve students' initiative and motivation.

In the cultivation of students' autonomous learning, teachers should cultivate students' active thinking ability. Teachers should adopt different methods and individualized teaching methods to improve students' learning initiative.

For example, teachers can adopt situational teaching methods to create teaching situations and integrate students into actual situations. This teaching method is focus on the students' practice and the interaction between environment and students, students participate in practical activities in the process of learning, improve their ability and improve their quality in practice. Teachers can also lead students to improve moral judgment standards in social practice activities. In specific practical activities, students can understand the society and understand the society in many aspects and in many aspects and can better shape the personality of the subject in social practice.

\section{Conclusion}

The ideological and political education is the focus of the public security colleges and universities education. In practice, we must pay attention to the education subject, the characteristics of taking a targeted education way. Education of the main body should be combined with students' characteristics to transform education mode to enhance the effect of education.

\section{Acknowledgements}

College Level Scientific Research Projects of Hubei University of Police in 2018: "A study of public security culture construction in the new era of Xi Jinping's socialist cultural confidence with Chinese characteristics" (No. ZN03) 


\section{References}

[1]. Li Meilan Zhang Junqing. Basic characteristics of education model of moral education in colleges and universities [J]. Chinese higher education research, 2016 (7)

[2]. Taoist Wang Liping. Theory of moral education and model [J]. Journal of Yangzhou university (higher education research edition), 2015 (6)

[3]. li. To strengthen the ideological and political education of the police team thinking [J]. Journal of public security education, 2016 (2)

[4]. Guo Xuguang. Political identity: the goal direction of ideological and political education [J]. Ideology theory education, 2015 (7)

[5]. Li Jianping. Theory on the cultivation of subject personality [J]. Hubei social science, 2015 (9)

[6]. Zhao Zhixin. Reflections on the construction of a new mode of moral education in universities [J]. Journal of Chongqing institute of technology, 2016 (9) 